\title{
PRESENT STUdiES AND HISTORY OF BURNING IN GREECE
}

\author{
L.G. Liacos \\ School of Agriculture and Forestry, \\ Aristotelion University of Thessaloniki, \\ Greece
}

\section{INTRODUCTION}

Greece, to those who know it only from archeological books and its ancient architecture, is associated with rocks, and bare mountains of white fine-granular marble, decorated by fine-sculptured temples, all built of white marble. Probably, the small size pine-tree grove, ideally matched with scattered columnar cypress and olive trees, which commonly constitute the frame that beautifies the ancient Greek landscape, do not prevent [readers] from wondering whether Greeks, being in an arid country, had no choice in selecting their building material.

However, all over the Greek territory, the climate, characterized by more or less long dry and hot summers (typical Mediterranean climate), is, in general, very favorable for the development of even dense forests.

No doubt, in prehistoric times Greece was totally covered with thick forests, with the only exception of the summits of high mountains, rising above the timber line.

The recently discovered bones, found in excavations near Pikermi a few kilometers east of Athens, belong to a prehistoric large and very robust animal, the habitat of which is confined to extent forest environment. That gives a very strong evidence that Attica was covered in unbroken forests.

Greek Mythology, on the other hand, says that Hercules killed the Kithaeronian Lion and the Elk of Artemis (Diana) in Peloponessos. This allows [one] to conclude that Peloponessos was covered with large forests, since lions and elk require a forest environment over large areas.
Moreover, Homer in his Odyssey calls the now bare Mount Noriton in the island of Ithaca "dense leaved" and the island Zakynthos "forest covered".

\section{HISTORY OF BURNING}

The destruction of the Greek forest largely began with the invasion of the country by various indo-German races. They started from the country around the Danube River, at the beginning of the 20th century B.C.

First, the Achains, a race purely nomadic, following the valley of the Axios River entered Greece, and arrived in Peloponessos through central Macedonia, Thessaly, Biotia, and Attica. Using fire mainly, they converted large forested surfaces to grasslands, in order to secure better feeding for their numerous livestock animals, or to open passages to grass-covered lands (alpine rangelands).

Second, the Doreans, a mountainous race entered from western Macedonia, and following the main mountain range went down as far as Peloponessos. They also converted large areas of forests to grasslands for the same reason, using the most effective tool, burning.

Naturally started wildfires, also, were a very common phenomenon all over Greece. Homer in Iliad ( $\Lambda$. 155) sings:

And as when consuming fire falls upon thick woodlands and the whiching wind beareth it everywhither and the thickets fall utterly as they are assailed by the onrush at the fire. 
Thoukidides, also, talking about the unexpected escape of Plataeans, while they were besieged by Spartans the summer of the third year of Peloponnisian war (429 B.C.), thanks to an unusual storm that followed a big fire the Spartans put all around the city, says:

And a conflagration arose greater than any one had ever seen up to that time, kindled, I mean, by the hand of man; for in times past in the mountains when dry branches have been rubbed against each other a forest has caught fire spontaneously therefrom and produced a conflagration.

Forbes, also, talking about the importance of fire in ancient technology, says that ancient man applied burning "to extend the forest fires to manure the cleared spaces."

Therefore, burning has greatly contributed to the present physiognomy of the vegetation cover and the whole ecosystem of Greece, not only as a tool in hands of economy making man, but as an important factor of the natural environment too.

It is rather certain that maquis and garrigues formations (see Figure 1), occupying at present about 15 percent of the total land area of Greece, are mainly a result of wildfires. Moulopoulos (1935) says that the coastal zone of the Greek peninsula from Albania to Pelopo-

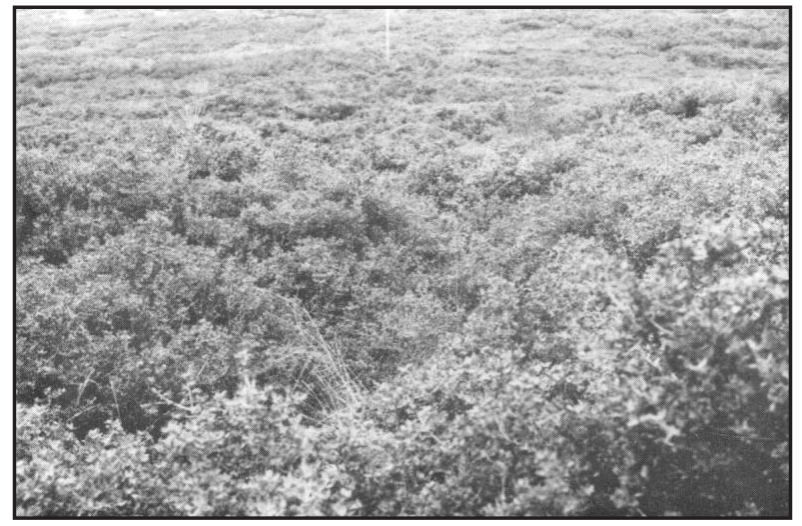

Figure 1. Maquis formation in Chalkidiki peninsula. nessos and from Peloponessos to Chalkidiki was in previous times covered with productive forests of Pinus halepensis Mill., P. brutia Ten., P. pinea L., and Quercus ilex L., interrupted only by very dense Fluviisilvae and Paludisilvae around the mouth of big rivers-like the Axios River in Macedonia-or by deciduous oak forests growing in isolated stands. And, he states, that the main reason of their substitution by maquis formation was the wildfire, caused, mainly, by man to improve, primarily, grass and browse production, and secondarily to expand his cultivated land (Figure 2).

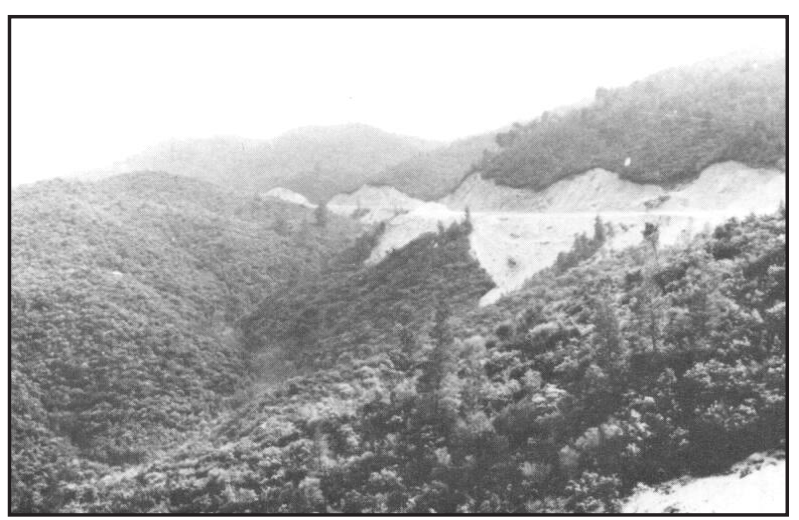

Figure 2. Gradual substitution of Pinus halepensis by maquis in Chalkidiki peninsula.

But ancient Greeks very early had seen that burning had also some beneficial effects.

Homer in Iliad (ø 12), talking about the retreat of Argites after they lost the battle, and trying to escape, says:

And as when beneath the onrush of fire locusts take wing to flee on to a river and the unwearied fire burneth them with its sudden oncoming and they shrink down into the water.

Virgil, also, in his Georgics (book I, 84-93) says:

Often, too, it has been useful to fire barren fields, and burn the light stubble in crac[k]ling flames; whether it be 
that the earth derives thence hidden strength and rich nutriment, or that in the flame every taint is baked out and the useless moisture sweats from it, or that heat opens fresh paths and loosens hidden pores, by which the sap may reach the tender blades, or that it rather hardens the soil and narrows the gaping veins, that so the searching showers may not harm, or the blazing sun's fierce tyranny wither it, or North wind's piercing cold.

Vassus Kassianos, too, refers to burning and its beneficial effects upon the crops and says in his Geoponica [Beckh 1895]:

The best manure of all for vegetables is ash, and being most fine and naturally warm, it will kill the fleas and worms and other small beasts

and also:

some people use instead of nitre ash to also kill caterpillars.

and further (book $\mathrm{I} \Gamma, 10-1)$ :

If you hunt ants and burn them, you will expel all ants that are left, as experience has taught us.

Letsas (1957) in his three volume Mythology of Agriculture reports that the ancients used to burn the stubble or the herbage and dry leaves to manure the fields. In Xenophon's Economics (XV III, 2) the famous Greek historian reports:

I imagine that the stubble may be burnt with advantage to the land, or thrown on the nature heap to increase its bulk.

\section{PRESENT STATUS OF BURNING}

At present, fire still constitutes a very important factor of the Greek wildland ecosystems. Wildfires in forests and rangelands are very common.

D. Kailidis (1972) reports that from 1956 to 1971 the average number of wildfires registered all over Greece per year amounted to 612, and had destroyed, on average, 10150 ha of forest and brushlands, with an estimated damage of about $\$ 7336000$. This represents 0.14 percent of the total forests and brushlands of Greece. More than 60 percent of the total burnt area is coniferous forest of Pinus halepensis and P. brutia of the lower Mediterranean zone, and maquis and garrigues formations. The surface burnt and losses from wildfires would be much greater, if forests in this zone were not broken in relatively small size stands by the interval of non-forested land. The author also reports that in more than 60 percent of the fires the cause was carelessness (cigarettes), or inadequate control of stubble burning in neighboring wheat fields, that spread the fire over to forest ground fuel (ground fuel in $P$. halepensis and $P$. brutia forests is very flammable) or brushlands.

D. Kailidis and A. Papagiannopoulos (1972) studying the litter moisture trend under Pinus brutia stands and in openings in the Forest Park of Thessaloniki-city, found that from June to October in 1968, and from May to November in 1969 , litter moisture content was less than 25 percent; this marks the critical point under which fuel burns very easily. In openings the accumulated grass litter had a moisture content even lower than that of pine-needle litter under the stands.

Generally, Pinus halepensis and P. brutia forests in Greece form relatively open stands, under the canopy of which grows a luxurious understory vegetation of evergreen, mainly, brush species and associated herbaceous plants, which dry-out during the summer months. 
This understory vegetation, intercepting in addition through all its depth the falling dead pine-needles, is very flammable. This creates a big fire hazard. The fire hazard is particularly high in Pinus halepensis forests, managed primarily for gum production. Gummed pinetree trunks with their wounds all around and gum droppings are very easy to burn, for they rapidly conduct the fire to the tree crown and to the forest canopy, in general, once started on the ground (Figure 3).

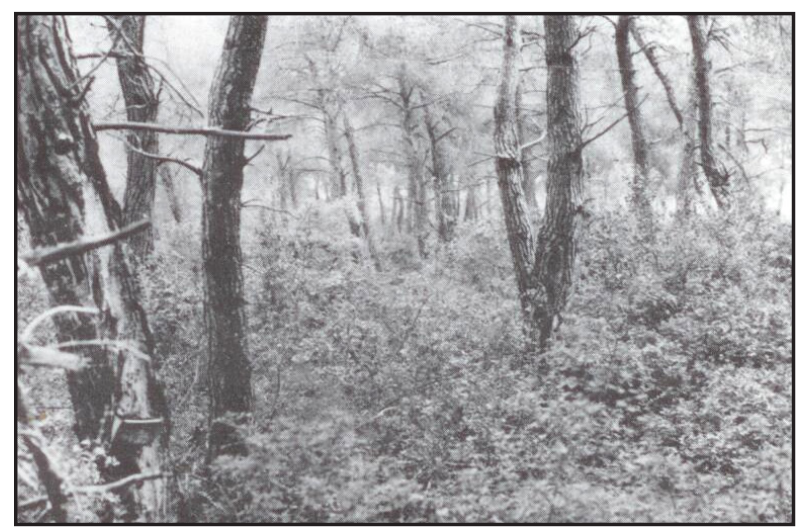

Figure 3. Pinus halepensis stand used for gum production in the peninsula of Chalkidiki.

Needless to say that with increasing tourist traffic and the mass outings of urban people from the noisy, air-polluted cities for outdoor recreation, fire danger is going to become great.

Brushlands, also, suffer big losses from wildfires every year. During the long rainless and hot summers the moisture content of their aerial part drops considerably, and it takes just a spark to start burning. Liacos and Moulopoulos (1967) report that moisture content of the browse - the most tender succulent tissues of the aerial part-produced by one of the main species of maquis formation, the Kermes oak (Quercus coccifera L.), drops down to about 40 percent in late summer. Certainly, the moisture content of the woody parts of the species, which constitute the bulk of fuel matter, is at that time much lower.
Burning is also used at present as a management tool. Wheat farmers almost all over Greece consider stubble burning a good technique for increasing wheat production. Livestock operators also in many districts use burning for range improvement. They practice it because they strongly believe in its beneficial effects, in spite of the general belief that burning is harmful, especially to the soil.

Farmers have seen that when stubble burning is practiced in autumn or in winter time, crops are better the following season than when no burning is applied. They specifically observed the following after burning:

1. Plowing of the field and soil preparation for reseeding is much easier and perfect, that secures better germination of seeds and better development of the seedlings.

2. Wheat seedlings show no chlorotic phenomena in spring, as is the case when stubble burning is not applied.

3. The season following stubble burning insect and disease attacks are less, and consequently crop damage reduced to a minimum.

4. Weeds are less abundant the season after stubble burning.

Agronomists are not in a position yet to give a definite and dependable answer to the problem. They experiment now on the various aspects of the problem. Livestock operators, on the other hand, of Thesprotia County (northwestern corner of Greece) use burning in low elevation rangelands every 4 or 5 years to control undesirable invaders and weeds. Weeds dominate in plant cover by the end of the fourth or fifth years after burning. It must be noted, here, that grazing in the area is practiced by sheep herders without any range management principle, and without any control as to the number of animals, the grazing period etc. 
Livestock operators have seen that burning of dry range vegetation late in summer:

1. Secures a satisfactory control of weeds and other undesirable plants.

2. Stimulates a growth of dormant plants and provides green forage although in small quantities, when vegetation is completely dry.

3. Secures a relatively higher quantity of forage (grazable) for at least the next 2 years.

This technique of burning has been authorized even by the responsible state agency, the Greek Forest Service, under the pressure of the livestock operators, who live at present in this area as semi-nomads. However, the plant cover and especially the soil have been deteriorated to a high degree. A backward trend of the range condition is evident. The very valuable grass species Andropogon distachyos L. is greatly decreasing in vigor and density, and the invasion of the range by a phrygana plant community (Cystus spp., etc.) is obvious.

Certainly, livestock people do not realize that burning alone, without the application of a rational and proper plan for the specific area management-use and improvement, not only fails to have the expected results, but besides it becomes the main cause of heavy degradation of the main resources of the range ecosystem, namely the vegetation and the soil (Figure 4).

Livestock operators also use burning, although without permission, for improving browse production in brushlands. Here again burning is practiced not properly and not prescribed by a management working plan, with the result, finally, of a more or less severe degradation of the vegetation cover and the soil (Figure 5).

\section{PRESENT STUDIES OF BURNING}

Fire, as it is easily concluded from the preceding analysis, continues to be an important

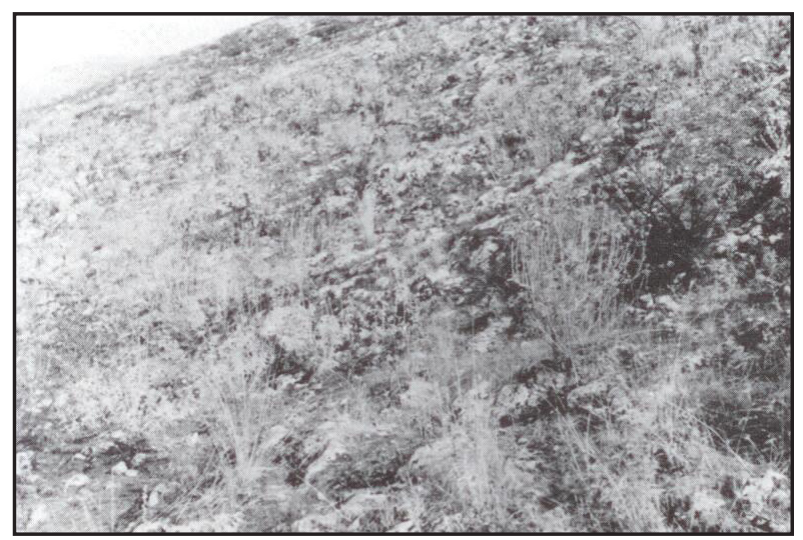

Figure 4. Degradation of burnt rangelands in Thesprotia County is evident.

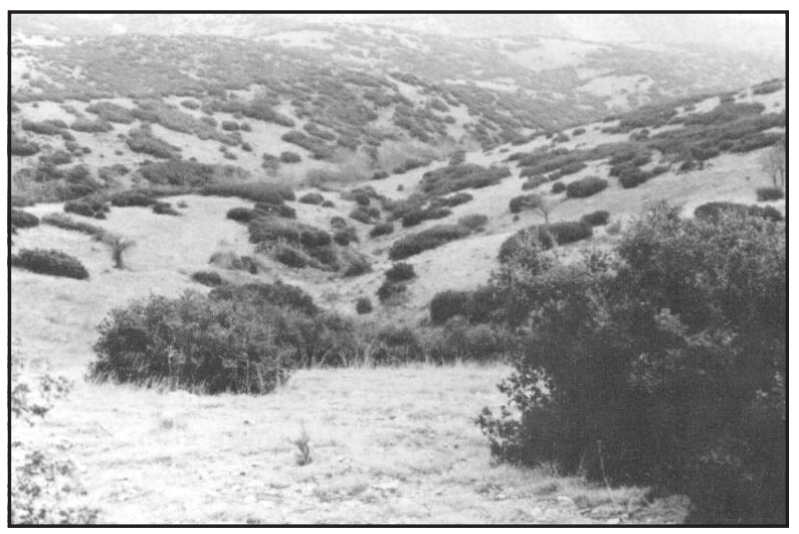

Figure 5. Progressive degradation of brush vegetation (maquis) and soil because of unwise burning and uncontrolled grazing.

factor even in the modified now wildland ecosystem that dominates, particularly, in the lower Mediterranean zone of Greece.

Moreover, all activities developed today for restoration of the wildland vegetation and the reestablishment of the forest primarily for protection and recreation purposes (environmental forests), magnify the importance of the fire factor and render it, I might say, dominant in the environmental forest ecosystem, under, especially, the rapidly increasing tourist traffic and the demand for outdoor recreation.

Upon the basis of these facts and considerations lie our studies on prescribed burning, inspired and guided by the relative research and application work done in the USA. 
We thought that burning might be a very valuable tool, and an unsubstituted servant in the management of Greece's wildlands, if properly used and manipulated with understanding. After a thorough analysis of the problem, it was concluded that prescribed burning might be indicated and valuable in management of the following three distinctive ecosystems:
A. In the coniferous forests of Pinus halepensis and Pinus brutia.
B. In the maquis formation.
C. In the high mountain grasslands, dominated by hard bunchgrasses.

The specific problems in each of these three ecosystems, and the experimental work planned and undertaken arc presented in the following discussion.

\section{Coniferous Forests}

In the coniferous forests of aleppo or brutia pine, naturally existing or artificially created in their natural area by reforestation, two main categories of stands can be distinguished.

Forests on good site. Growth conditions allow here the development or the creation and maintenance of thick stands during at least the first half of their rotation time.

With the progress in age of the stand one can see:

1. A number of trees dying-off under the effect of the severe competition developed among trees (natural thinning) having no commercial value, and thus representing an actual loss for the forest business. For the same reason all understory vegetation is gradually dying-out too (Figure 6).

2. A continuous increase of dead branches of living trees remaining

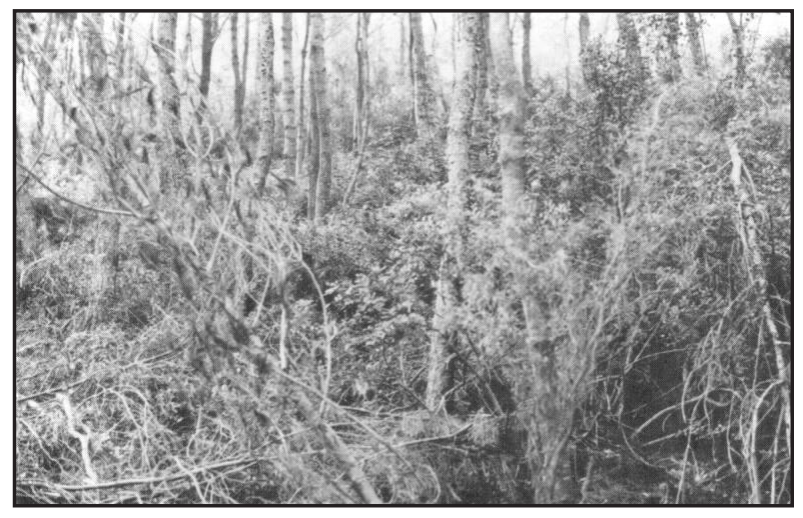

Figure 6. Pinus halepensis stand about 30 years old. Dominated trees and understory brush dying-off under the effect of competition.

in place, decreasing thus the quality, and consequently the value of the timber produced, even if after several years that they may be broken, but always in a considerable distance from the tree-trunks (Figures 7 and 8). Under Mediterranean climate, and particularly in its lower part, natural pruning, that constitutes in classical silviculture one of the reasons justifying thick stands, seems to be an empty word. Decomposers, the main agent in natural pruning, can not be very active, because moisture is insuffi-

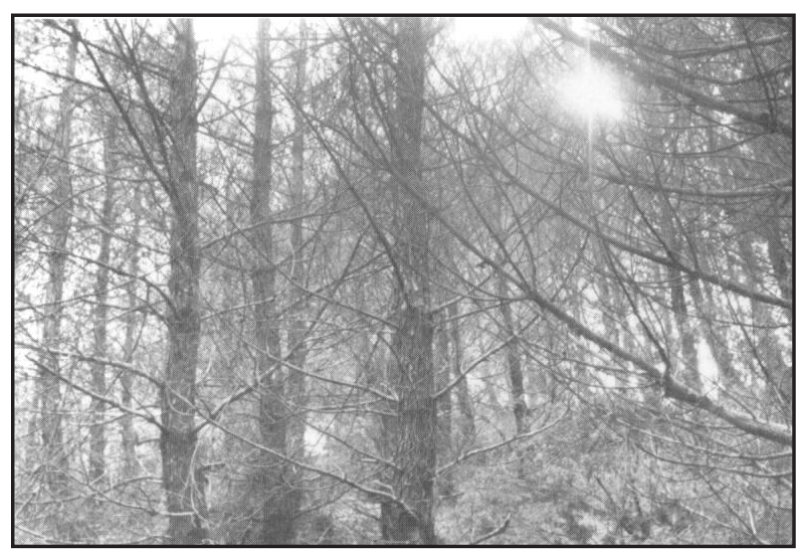

Figure 7. Dead branches remaining in place in an artificially established 30 year old stand of Pinus brutia. 


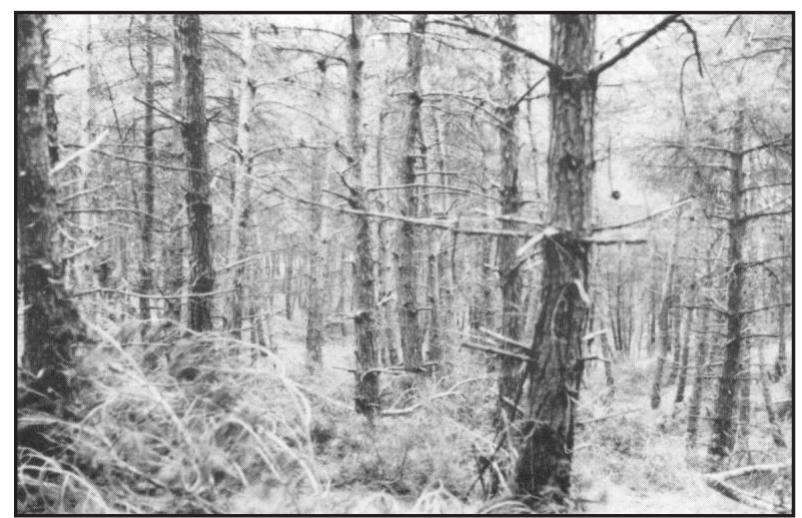

Figure 7. Artificial stand of Pinus brutia about 35 years old immediately after the first thinning. Notice the broken dead branches in the distance from trunks.

cient when temperatures are sufficiently high in summer time.

3. An accumulation on the ground of pine needles in thick undecomposed layers, and a storage of dead pine needles upon the dead branches of trees or upon understory woody vegetation (Figure 9). The decomposition of the litter is very, very slow for the same reason mentioned above.

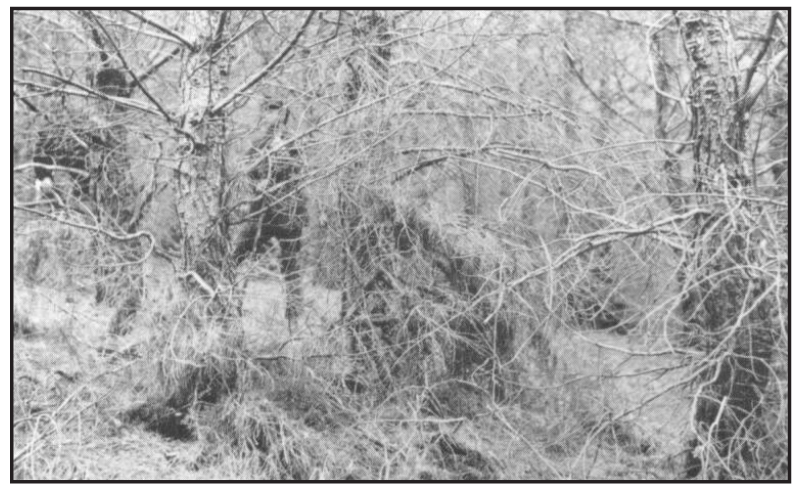

Figure 9. Artificial stand of Pinus brutia 30 years old with thick layers of undecomposed needles on the ground and upon dead branches.

4. A large volume of slash left upon the ground after each thinning of the stands, once the diametre of the trees reaches commercial value.
5. In the older stage during the second half of the rotation time the stands are thinned naturally, for they are constituted by light tolerant (light demanding we might say better) species. The density of the stands is decreasing as they approach the end of the rotation time. Under such relatively open stands a dense understory of woody and herbaceous vegetation grows (Figure 3), which in summer time is very flammable; its moisture content is then very low. This is one of the reasons for which $P$. halepensis and $P$. brutia stands are not thinned properly in early age stages with the result of a lower value of timber produced.

6. After the final cut of the stand at the end of the rotation time the understory vegetation grows extremely vigorous and dense in absence of any competition from pine trees. Under such conditions natural regeneration becomes uncertain, or it completely fails. On the other hand, artificial regeneration can be warranted only with high cost.

Forests on poor site. Here the stands grow more or less open from a very young age. Under such stands an understory brush and/or herbaceous vegetation is developed, and a heavy flammable fuel is stored on the ground, much the same way as that under aged stands growing on good sites, creating similar problems from the very beginning in each stand.

It is certainly clear after this brief analysis that the fire hazard in such coniferous forests of the lower Mediterranean climate is very big.

Obviously, the elimination of the accumulated on the ground highly flammable fuel, and furthermore the prevention of accumulation of new fuel on the forest floor is of paramount importance. 
One way to do this is to take away from the forest any flammable matter every time its quantity exceeds the security limits. However, this creates heavy expenses, increasing, finally, very much the cost of the timber and/or gum produced, and the offered services of protection, recreation and landscape improvement as well.

Certainly, prescribed burning might be a suitable and extremely valuable tool, and a very good solution of the problem, under conditions we knew whether, how, when and where this technique could be applied in Greece. And furthermore, if following prescribed burning the establishment and maintenance of an understory vegetation of forage plants could be easy, then the practice of a proper grazing by livestock and/or wildlife animals could not only prevent the accumulation of fuel under the forest canopy, but it would, in addition, produce a considerable income instead of expenses. Besides, this would minimize the competition of the understory vegetation with trees, as far as soil moisture is concerned that constitutes the main limiting factor of plant growth in the Mediterranean zone, and thus greatly benefit the forest and consequently timber production. This would, perhaps, also encourage silviculturists to thin properly the stands for maximizing the value of the timber that can be produced in proportion to site potential, since they would not be annoyed by an undesirable understory vegetation. In addition, once the understory vegetation could be easily controlled even with benefit (grazing), the application of fertilizers for further increase of timber and forage production would be possible and economically justified.

With this in mind as the basic hypothesis, and in view of the facts and experience gained in the USA, a number of experiments were planned and have been put under way since 1968 in Pinus brutia stands. With this net of experiments it is hoped and expected to have valuable results, that properly analysed and interpreted, would answer the general problems created by the use of prescribed burning in for- ests of Pinus halepensis and Pinus brutia. More specifically it is expected to answer the questions which came out of the analysis of the problem made above, that constitute the general hypothesis of the study.

Up to date results. Although it is very early to have valuable conclusions, a number of data and observations could be of interest. The results of the compiled up-to-date data are as follows:

1. It is rather certain that Pinus halepensis and Pinus brutia endure quite well, prescribed burning of brush understory vegetation at an age of 30 years and thereafter. Their rhydidome is at that age thick enough to protect the cambium from the released heat (Figure 10).

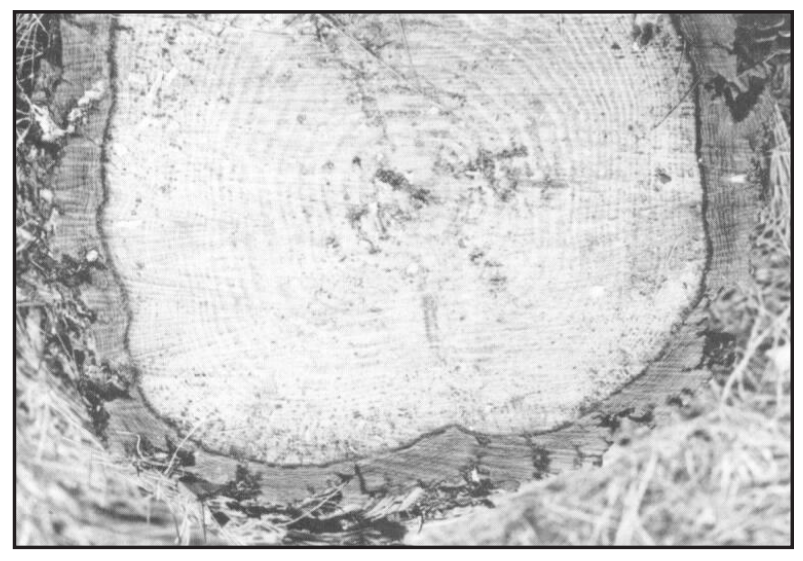

Figure 10. Rhytidome of Pinus brutia 30 years old. One can see the decrease in growth after the 15 th year because of the high density of the stand. Thinnings should begin 10 years earlier at least.

2. The temperature of mineral soil under burnt brush and slash is hardly affected, when burning is applied in winter 2 or 3 days after a rain good enough to soak well under the litter humus. Measurements made showed $15^{\circ} \mathrm{C}$ after fire ran over it, while air temperature was $16^{\circ} \mathrm{C}$. Thus soil was not affected at all. 
3. Soil nitrogen was found to be higher in burnt than in unburnt plot the first year after burning. It was 0.189 percent and 0.126 percent respectively.

4. The establishment of seeded orchardgrass (Dactylis glomerata L.)-after burning in intensively thinned plot was satisfactory. Volunteers, among which were many legumes, colonised the soil after burning in satisfactory degree. Main volunteers: Festuca ovina L., Aristella bromides (L.) Bertol., Andropogon ischaemum L., Koeleria cristata Pers., Phleum spp., Trifolium purpurem Loisel., Trifolium angustifolium L., Trifolium arvense L., Vicea spp., and Poterium sanguisorba L.

5. In burnt plot, after three consecutive thinnings of the 30 year old stand, that lowered the tree number per hectare from 1100 to 450, total volume (standing and taken by thinnings) was equal to that of the plot treated according to conservative silvicultural rules (see Table 1 and Figure 11). Also the increment of standing trees after thinning was much higher in the intensively thinned and burnt plot (Figure 12).

6. Pine regeneration 2 years after last burning was very good. In the unburnt plots many seedlings were found from germinated seed during past fall, but almost none from ger-

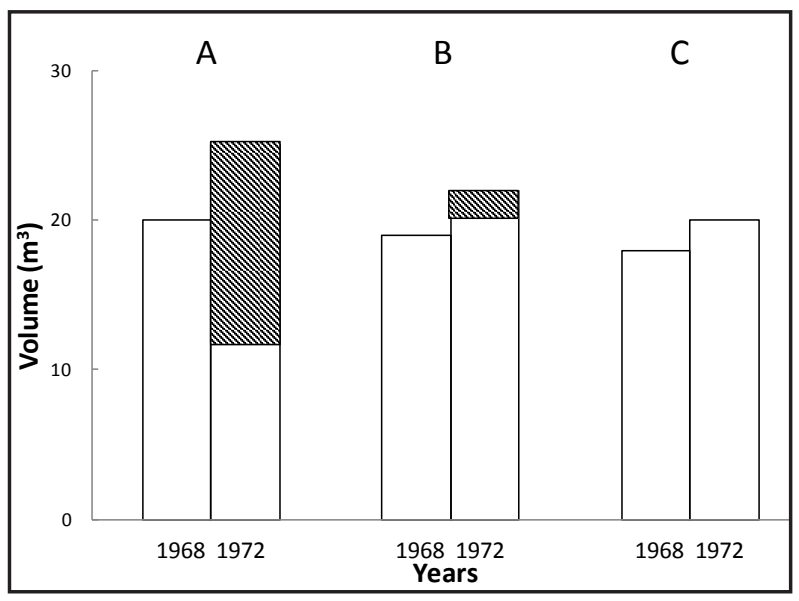

Figure 11. Volume of standing (open column) and thinned-out (cross hatched) trees in Pinus brutia plots: A. Intensively thinned and burnt, B. Lightly thinned, C. Control.

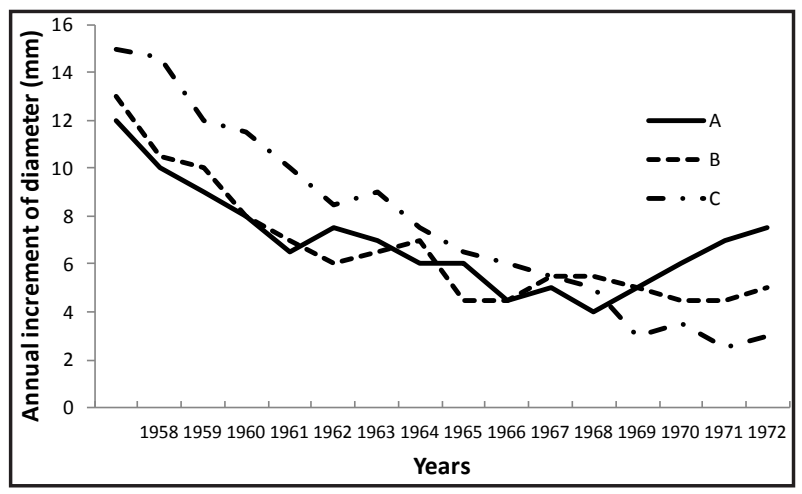

Figure 12. Increase in diameter of Pinus brutia trees in plots: A. Intensively thinned and burnt, B. Lightly thinned, C. Control.

minated seeds in previous years. Table 2 shows the pine seedlings found in February 1973 in burnt and unburnt plots.

Table 1.

\begin{tabular}{lccccc}
\hline Treatments & $\begin{array}{c}\text { Volume in } \\
\mathbf{1 9 6 8}\end{array}$ & $\begin{array}{c}\text { Volume of } \\
\text { thinnings }\end{array}$ & $\begin{array}{c}\text { Volume in } \\
\mathbf{1 9 7 2}\end{array}$ & $\begin{array}{c}\text { Total } \\
\text { volume }\end{array}$ & $\begin{array}{c}\text { Increments } \\
\text { (\%) }\end{array}$ \\
\hline $\begin{array}{l}\text { Intensive thinning- } \\
\text { prescribed burning }\end{array}$ & 20.53 & 12.99 & 12.36 & 25.35 & 23.47 \\
Conservative thinning & 19.34 & 1.52 & 21.56 & 23.08 & 19.33 \\
Control & 17.93 & - & 18.76 & 18.76 & 4.64 \\
\hline
\end{tabular}


Table 2.

\begin{tabular}{lccc}
\hline Treatments & $\begin{array}{c}\text { Intensive thinning- } \\
\text { prescribed burning plot }\end{array}$ & $\begin{array}{c}\text { Conservative thinning } \\
\text { plot }\end{array}$ & $\begin{array}{c}\text { Control } \\
\text { plot }\end{array}$ \\
\hline Seedlings less than 1 year old & 2 & 17 & 29 \\
Seedlings older than 1 year & 15 & - & - \\
\hline
\end{tabular}

\section{Evergreen Brushlands}

Maquis brushlands are now used by browsing animals such as goats and deer mainly. Their value as browse-land is not very high. Liacos and Moulopoulos (1967) found that browse production of this land in good condition does not exceed for the area studied, 750 $\mathrm{kg} \mathrm{ha}^{-1}$ air dry. Liacos (unpublished data, University of Thessaloniki, Greece) in a conversion study from brushland to grass by seeding Dactylis glomerata, Phalaris tuberosa L., and Trifolium hirtum All. after mechanical clearing of brush, found that grass forage production was about $500 \mathrm{~kg} \mathrm{ha}^{-1}$ air dry.

With this in mind and the fact that wildfire hazard is very high in this vegetation type a comparative research study was started last year. Prescribed burning is used as the main tool of conversion, followed by planting of a mixture of seeds of Lolium multiflorum Lam. (used as the main competitor against brush sprouts), Dactylis glomerata, Phalaris tuberosa and Trifolium hirtum. On the other hand, brush vegetation in the remaining underbrush covered plots is improved by proper manipulation of brush individuals and the whole community as well, for reaching maximum browse production (Figure 13).

The purpose of this experiment is to find out:

(a) Whether brush conversion by prescribed burning constitutes an efficient technique.

(b) How to control brush sprouts after burning.

(c) What is the production of forage as compared to browse produced.

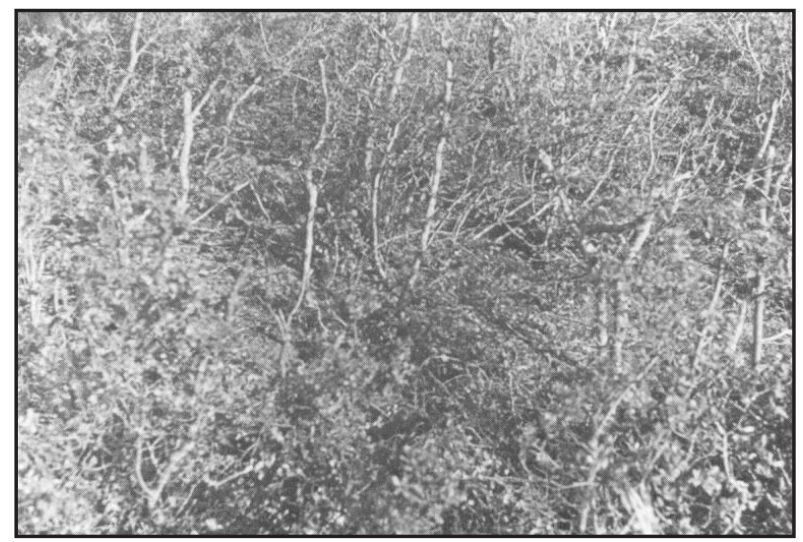

Figure 13. Brush vegetation treated for high browse production.

(d) Which is the technique to follow in order to insure a good establishment and maintenance of forage cover.

\section{High Mountain Grasslands}

Prescribed burning has been also used in a research study to improve forage production of high mountain rangelands, dominated by hard bunch-grasses, grazed for centuries only by sheep and goats.

Large quantities of undecomposed litter on the ground surface prevent the seedlings from rooting into the mineral soil, and are easily and regularly uprooted by grazing sheep.

The experiment has been established at an elevation of $100 \mathrm{~m}$ the fall of 1971 in Mount Phalacron in northern Greece, representing an area of more than 10000 ha in this mountain and manyfold larger area all over upland Greece.

Burning was applied in fall and in spring immediately after snow melt in combination 
with and without chemical fertilization (Figure $14)$.

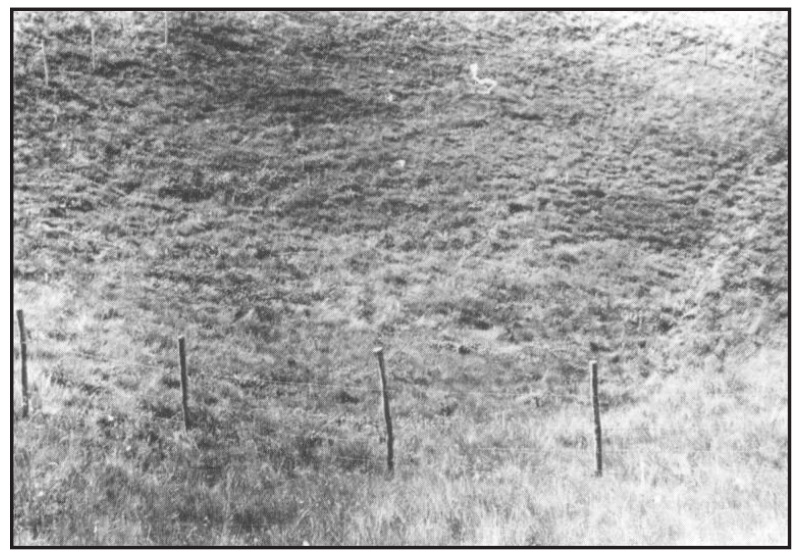

The first year results show that burning improved the quality of the forage; it was more tender and palatable. Its crude protein content was higher than in unburnt forage, while quantitatively no difference was found thus far.

Reprinted and condensed with permission from Liacos, L.G., 1974. Present studies and history of burning in Greece. Tall Timbers Fire Ecology Conference Proceedings 13: 6595, by Tall Timbers Research Station, Tallahassee, Florida, USA.

Figure 14. Experimental plot in high mountain bunch-grasslands. Fall and spring burning is checked in combination with and without mineral fertilization for forage improvement.

\section{LITERATURE CITED}

Beckh, H., editor. 1895. Geoponica sive Cassiani Bassi scholastici de re rustica eclogae. Teubner, Leipzig, Germany. [In Greek.]

Kailidis, D., and A. Papagiannopoulos. 1972. Litter and soil moisture under Pinus brutia stand and in an opening. Pages 256-287 in: The Year Book of Agriculture and Forestry Department. University of Thessaloniki, Greece. [In Greek.]

Kailidis, D. 1972. Forest and grazing land fires in Greece during 1971. University of Thessaloniki, Greece. [In Greek.]

Letsas, A. 1957. Mythology of agriculture. Volume III. Triantaphylou Sons, Thessaloniki, Greece. [In Greek.]

Liacos, L.G., and C. Moulopoulos. 1967. Contribution to the identification of some range types of Quercus coccifera L. Forest Research Center of Northern Greece, Thessaloniki, Greece. [In Greek.]

Moulopoulos, C. 1935. Observations and research on the regeneration of burnt forests of Pinus halepensis. Pages 1-24 in: The Year Book of Mathematics and Physics Department. University of Thessaloniki, Greece. [In Greek.] 